\title{
On the impact of tourism on the economy of Baja California Sur, Mexico: a SAM approach
}

\author{
M. Angeles, A. E. Gamez \& A. Ivanova \\ Department of Economics, \\ Universidad Autónoma de Baja California Sur, Mexico
}

\begin{abstract}
The economy of Baja California Sur (BCS), in northwestern Mexico, has been anchored on tourism and related activities, particularly in the last two decades. This is apparent in particular in the Los Cabos region (on the southern tip of the state); La Paz (the state capital) has a more diversified economic base (which dilutes the direct impact of visitor flows). Yet, if the broad set of infrastructure and other economic necessities of Los Cabos are taken into account, the indirect impacts are significant. The state's indicators of supply and demand for tourism services place La Paz in a distant second place, after Los Cabos, but tourism's relevance extends beyond the direct impacts due to visitors who choose the state as their holiday destination: overall, about $40 \%$ of the local economy depends on tourism-related activities. This paper analyses the interrelations of tourism with other sectors of the BCS economy and, in particular, its impact on the distribution of income at the state level. This could contribute to further comparisons in relation to other small, open regions.
\end{abstract}

Keywords: tourism impacts, Baja California Sur (Mexico), SAM approach, small regions.

\section{Introduction}

Tourism in Baja California Sur (BCS), a region separated by the Sea of Cortes from mainland Mexico, developed on a small scale until 1960, and grew in strength over the next two decades owing to the growth of imports from the United States for resale to Mexican nationals. These flocked to the state to buy those goods, at a time when the rest of the country's economy was protected by high tariff levels. As a result, La Paz flourished as a trade and tourism Mecca, 
but the trade liberalisation processes that began during the De la Madrid presidency in the early 1980s (which deepened during the administration of Carlos Salinas de Gortari, 1988-1994) changed this situation. The costadvantages of trade in imported goods that hitherto favoured BCS were eliminated and visitor flows diminished. However, the effects of trade reductions on tourism were later to be more than compensated. Through the implementation of a scheme of "integrally planned" tourism centres (CTIP, for the Spanish initials) by the Fondo Nacional para el Turismo (National Tourism Fund, FONATUR) in the Los Cabos area, tourism flows not only regained their previous levels but reached unprecedented dimensions. From its beginnings as a small fishing and agricultural community, the Los Cabos region has turned into one of Mexico's most dynamic tourism destinations, focusing on traditional tourism (sun, sand and beaches, sport-fishing, and entertainment); the region was host to 1.1 million visitors in 2007 (the last year for which official data are available), which represented $73 \%$ of the state's total [1]. Its dynamism as a source of jobs has meant an extremely high rate of population growth (an average of $10 \%$ annually during the last decade), as well as the development of tourism, communications and transport infrastructure. Los Cabos boasts over 14,000 hotel rooms, and its appeal to high-income foreign visitors unquestionably generates an enormous (though unquantified) economic impact.

These high rates of economic and demographic growth have been accompanied by strong negative externalities and undesired by-products. Population growth has exceeded the provision of housing, basic infrastructure, schools, health clinics, and recreation and cultural facilities. To this one must add the growing degradation of the environment and landscape, as well as a growing scarcity of water, as local aquifers prove to be insufficient to meet the demand of society and tourism. In this respect, the construction of over 40 (on-going or proposed) tourist and second home megaprojects with multiple golf courses in an arid zone, such as BCS, seems incompatible with any true notion of sustainability. Bearing in mind that in a golf course each square metre requires 9 litres of water per day, and that an 18-hole course can cover an area of 350,000 sq. metres, the opportunity cost of its irrigation would be equivalent to providing water to a town of 10,000 people [2].

Even though alternative tourism, with its low environmental and social impact has been at the forefront of official pronouncements on (and announcements of) public policy towards tourism, in practise tourism activities have focused on high economic, social, environmental, and ecological impacts. The construction of large, "self-sufficient" resorts has now been complemented by the construction of large second-home projects (for retired US. And Canadian baby-boomers), as well as a proposed string of marinas, some of which are already in place, each with up to 400 yacht slots (the former Nautical "staircase," of the Fox years, now reborn as the Sea of Cortes Project). As a result, speculation on land and real estate has been rampant for the past 5 or 6 years [3].

The above underscores the lack of a state development programme that can promote economic diversification and social and environmental equilibrium. Until now, government strategies and actions have taken as a given that the 
promotion of private (largely foreign) investment in tourism "developments" or resorts is to be the strategy for economic development and jobs growth. Although we do not deny the importance of increasing employment, in our opinion there should be a more careful screening of investment projects, to ensure that jobs announced are actually jobs created, as well as a follow-up on the creation of more permanent - and well paid - direct and indirect employment. This is an important point given that most jobs are generated in the low paying subsectors of construction and services at the start of a given project, and by definition these places tend to be temporary. On the other hand, there is a clear division of labour by type of qualification, which favours non-locals.

\section{Employment and value added}

The announcement in the local press in 2008 [4] of investments in La Ribera (east of Los Cabos) in the amount of one billion USD, of an additional billion USD in La Paz, of 5.2 billion USD in Loreto (on the Sea of Cortez, by the Loreto Bay Company), and a further 3.3 billion in Los Cabos (Colinas del Puerto y Cabo Cortés), are not accompanied by serious environmental impact studies, social and/or environmental contingency plans, or by a public policy package that suggests the existence of a rational planning scheme for the utilization of environmental resources. Everything indicates that the scenic beauty, large territorial extension, and low population density of BCS are seen as unlimited resources that give carte blanche to the unending multiplication of resorts, golf courses, and residential complexes, with no obligation or provision on the part of investors in terms of immediate or future effects of their activities. As well, no consideration is taken of the fact that under Mexican federal law all beaches are public property, from which the population cannot be denied access; routinely, however, these resorts and complexes are fenced off, and accesses restricted to residents, the local population being displaced and excluded. Even for projects touted as environmentally friendly and socially conscious, there is no follow-up on their impacts.

Moreover, as we said elsewhere [5]:

"... It is surprising that in a state "with a great vocation for tourism" above everything else, the government has not seen fit to follow the example of the Federal authorities, or that of other (foreign) tourism destinations (Hawaii comes to mind), in constructing and publishing separate (satellite) accounts for tourism. Given this lack, there is no way to know what will be the impact on the local economy of any of the projects that are periodically announced, neither on the generation of income, nor on the creation of jobs. In this way, investment figures are mere numbers, empty of economic meaning; they give the impression of continuous growth and development, but fail to provide the substance.

The enclave nature of economic activities in BCS, in the sense that they have close connections with external enterprise, but lack strong internal linkages complicates the analysis, since it implies that a large part of income generated within the state filters to the outside. On the other hand, direct employment 
projections seem to be ad hoc numbers, ad hoc, while those for indirect employment seem both unreachable and unjustified. The high cost of job creation is also to be underlined. If, in the absence of official figures, one believes the numbers given by the press or the Internet for the afore-mentioned La Ribera project, a one-billion-USD investment would generate only 3,000 jobs. This would mean that each job would cost 333,333 USD; estimated in pesos (at the rate of 14 per USD), each direct job would cost 4.7 million pesos and each indirect job, 2.5 million. Even in the absence of specific data, it is logical to assume that state and local governments will need to spend on infrastructure, health, education, and public services in general, so that one may well question the effectiveness - in terms of the increase of the well-being of the local population - of investments justified by the creation of jobs that may well be fictitious, and the wages, beneficiaries, and time-frames of which are floor all intents simply a big question mark.

The lack of precise information that goes beyond the mere advertising of this or that Project is not a monopoly of the state authorities. The use of data published by the federal government does not come with a straight-forward guaranty that one will learn what one needs about the tourism sector. The share of value-added generated by tourism is a case in point. In 2004, latest year for which state GDP data are available from the Mexican government [6], GDP for BCS stood at 9.2 billion, of which $30 \%$ originated in the Finance, insurance, and real estate sector, $18 \%$ in Commerce, restaurants and hotels, and $11 \%$ in Transport, warehousing, and communications. We estimate that $90 \%$ of the first sector should be attributed to real estate activities and, if we suppose (with justification, see Angeles [7]) that half of the second sector and half again of the third are related to tourism, then we find that $40 \%(27+9+4)$ of GDP depend on tourism activities.

However, the 2004 Economic Census, recently made available at the local INEGI [8], office, reveals the following information:

Table 1: $\quad$ Tourism-related sectors ( $\%$ of total).

\begin{tabular}{|c|c|c|c|c|c|}
\hline Sectors & $\begin{array}{l}\text { Production } \\
\text { units }\end{array}$ & Employment & $\begin{array}{c}\text { Wages } \\
\& \\
\text { salaries } \\
(\mathrm{W} \& \mathrm{~S})\end{array}$ & $\begin{array}{l}\text { Value } \\
\text { added }\end{array}$ & $\begin{array}{c}\text { W \& S/ } \\
\text { Value } \\
\text { added } \\
(\%)\end{array}$ \\
\hline Estate agents & 2.5 & 1.6 & 1.2 & 2.4 & 16.7 \\
\hline Recreation & 0.8 & 0.8 & 0.6 & 0.4 & 53.0 \\
\hline $\begin{array}{l}\text { Restaurants and } \\
\text { hotels }\end{array}$ & 9.2 & 16.2 & 14.3 & 11.1 & 42.8 \\
\hline - $\quad$ Hotels & 1.2 & 8.2 & 9.1 & 6.6 & 46.0 \\
\hline $\begin{array}{ll}- & \text { Restaurants } \\
\text { and bars }\end{array}$ & 7.2 & 8.0 & 5.2 & 4.5 & 38.0 \\
\hline Transport & 2.8 & 4.4 & 6.2 & 7.2 & 28.4 \\
\hline Total tourism & 23.7 & 29.2 & 21.8 & 32.2 & 37.7 \\
\hline Total BCS & 100.0 & 100.0 & 100.0 & 100.0 & 32.8 \\
\hline
\end{tabular}


According to the Census, the state's aggregate value added for 2003 was 11.3 billion pesos, thus exceeding INEGI's estimate of the state's GDP (9.2 billion) by almost $20 \%$. There is no indication of the reasons for this large discrepancy between accounts which, theoretically at least, are meant to measure the same thing, i.e., the value of the flow of goods and services produced in the region during the year in question. Equally troubling is the fact that, according to Census figures, real estate represents a mere $2.4 \%$ of value added, as compared to the almost 30\% reported in the GDP accounts. Otherwise the Census data seem to reflect adequately the weight of the tourism sector in the BCS economy: $23.7 \%$ of production units (establishments), $29.2 \%$ of employment, $21.8 \%$ of wages and salaries, and $32.2 \%$ of value added.

\section{Effects of tourism on incomes}

Several important anomalies are revealed when one estimates the share of wages in total income (value added) generated. For example, wages and salaries ("remunerations", in the Census terminology) constitute $16.7 \%$ of income in the estate agents sector, $53 \%$ in recreation, $42 \%$ in restaurants and hotels, and just $28 \%$ in transport. Profits exceed $50 \%$ of income in each and every tourismrelated activity; for the sector in general, $37.7 \%$ of value added corresponds to wages and salaries, the rest being (mostly) profits. Clearly, tourism in BCS has been a very good deal for those in charge of it, a fact that is easily shown by using to that effect the state's Social Accounting Matrix (SAM), which shows total remunerations for 18 sectors of the BCS economy, allocated by quintile [9]. Table 2 shows the relevant tourism-related sectors.

Table 2: $\quad$ Tourism-related remunerations by quintile in BCS (\%).

\begin{tabular}{|l|r|r|r|}
\hline Quintile & Estate agents & Restaurants/Hotels & $\begin{array}{r}\text { Entertainment } \\
\text { and recreation }\end{array}$ \\
\hline Q1 & 0.26 & 2.28 & 2.28 \\
\hline Q2 & 1.82 & 9.07 & 9.07 \\
\hline Q3 & 3.99 & 14.24 & 14.24 \\
\hline Q4 & 9.18 & 25.51 & 25.51 \\
\hline Q5 & 84.75 & 48.90 & 48.90 \\
\hline
\end{tabular}

Considering that each "quintile" in this context represents $20 \%$ of the state's total homes, these results are impressive in terms of the enormous inequality that they point to in the distribution of wages and salaries amongst the state's homes. Thus, whilst the group of homes with the highest income level (by this measure: property incomes were not included), Q5, receives $85 \%$ of the remunerations generated in real estate, the lowest group (Q1) gets only $2.6 \%$. In the restaurants and hotels sector, the highest income quintile gets about half of total remunerations; the lowest receives just $2 \%$.

In order to measure the tourism sector's sensitivity to exogenous changes, Angeles et al. [9] used the state's SAM to simulate a 100 million peso 
investment increase in the Restaurants and hotels sector, taken as representative of overall tourism activities. The model sought to measure the increase in the incomes of certain sectors of the economy following the rise in investment, and the results were as shown in Table 3, which shows the five sectors where the expansionary effects are greatest (including, of course, the sector where the shock originates).

Table 3: $\quad$ Sectoral effects of a 100-million peso investment rise in the restaurants and hotels sector.

\begin{tabular}{|l|r|}
\hline Sector & $\begin{array}{r}\text { Millions } \\
\text { of pesos }\end{array}$ \\
\hline Restaurants and hotels & 203.25 \\
\hline Finance and insurance & 33.67 \\
\hline Other manufacturing & 22.71 \\
\hline Professional services & 19.45 \\
\hline Commerce & 17.84 \\
\hline
\end{tabular}

Evidently, the impact of the new investment is largest in the sector directly affected, where production rises by more than 200 million pesos. The implication is that the multiplier effect in Restaurants and hotels is a bit more than an additional unit of production (and income) for each unit of investment (since that variable rose by 100 million pesos). Other sectors of the BCS economy have more significant multipliers; notable examples are construction and food processing. Four other sectors, from finance and insurance to trade, generate income totalling about 85 million pesos, for an overall $\$ 188$ million in new production.

The impact of the 100 million peso increase in investment in the restaurants and hotels sector on incomes per quintile once more underscores the state's unequal distribution of income: the richest quintile gets almost 80 million pesos (of the slightly more than 100 million pesos of new income generated in restaurants and hotels, whilst Q3 and Q4 receive 44 million. The share of the lowest quintile is minuscule.

\section{Final remarks}

Our data show that the importance of tourism as the leading sector of the BCS economy, and the detonator of its growth, is quite evident. In the last five years, so-called tourism development projects along the BCS coastline have increased notably, expanding towards rural regions far removed from the Cabo San LucasSan José del Cabo tourist corridor, the jewel in the crown of the state's tourism sector, where these activities have been centred since their consolidation at the end of the 1980s and the beginning of the 1990s. Thus, significant parts of the municipalities of Comondú and Mulegé (in the middle and northern portions of the state), and - even more importantly - adjacent areas to Loreto and La Paz, 
have become investment magnets, imitating the more notorious "developments" in Cabo del Este, the part of the Los Cabos municipality fronting the Sea of Cortes. Government authorities (federal, state and municipal) promote and justify such developments in the name of job and infrastructure creation.

But if the Los Cabos CTIP is an example of the economic success of tourism, it is also proof that unregulated private interest, when combined with a weak and covetous government, indifferent to the general good, can generate unfortunate (though preventable) distortions. A clear example of this is the fact that in Cabo San Lucas, public spaces of incalculable value for the state in general, and for tourism in particular, have been done away with, as shown by the destruction of the former Coast Road, or Malecón (in a sun and beach destination par excellence!), or, indeed, the existence of large "misery belts" of marginalised population, side by side with some the most expensive hotels in Mexico. In addition, in a state lacking a strategy for the development of human capital, the provision of services for high-income tourists (the main group of visitors) has been shown to rely of qualified foreign (or extra-regional) employment. The low illiteracy levels and (still) relatively high, though falling, levels of income per head certainly point to a success story, when compared with other Mexican jurisdictions. But one would think that these same conditions would obligate the authorities, the private sector, and "civil society", to construct development strategies that promote well-being through diversification and endogenous growth. At best, BCS is overly dependent on tourism, with the well-known consequences of relying on a single sector for development; at worst, its recent growth has been based on land speculation and the plunder of the environment, while excluding the population at large both from the process and the benefits, even though not from the more negative aspects and consequences.

In sum, it is essential that a rigorous process of medium and long-term planning of tourism activities be put in place. This would imply a real state-wide development plan in order to avoid unbalances and pressure over scarce and vulnerable natural resources in the region, water among them. An adequate planning that prevent vial congestions such the ones in city entries of La Paz and Cabo San Lucas not only would solve the problem of urban image deterioration, but also help preserve the landscape that attracts visitors in the first place, would improve the quality of life of local inhabitants, and reduce the costs for producers and users.

Finally, the present global financial and economic crisis, having started in the United States (the state's main source of tourists and tourism investment) provides further evidence of the vulnerability of regions, such as BCS, that rely on the growth of that sector as the only (or the main) strategy for development. This fact, which tends to be forgotten when the economy is booming, must be seriously rethought when recession hits. If indeed a time of crisis is also a time for opportunity, Baja California Sur has, at this time, a moment of respite to assess the environmental and social consequences of its development model. This will require a non-myopic public sector that places the public welfare at the centre of its activities, as well as the vigorous participation of the population in decision-making. 


\section{References}

[1] Centro Estatal de Información (CEI), Documento de trabajo, Secretaría de Promoción y Desarrollo Económico, Gobierno del Estado de Baja California Sur: La Paz, BCS, 2009.

[2] The Guardian, www.guardian.co.uk/environment/2004/jun/18/water.spain

[3] Steinitz, C., Faris, R., Flaxman, M. Arizpe, O., Angeles, M., Cariño, M. \& Maddock, T., Alternative Futures for the Region of La Paz, Baja California Sur, Mexico, Fundación Mexicana para la Educación-Ambiental \& International Community Foundation: Mexico City, 2006.

[4] El Sudcaliforniano, www.oem.com.mx/elsudcaliforniano/notas/n626807. htm

[5] Angeles, M., Gámez A. E., \& Ivanova, A, Consideraciones sobre turismo y economía en Baja California Sur. Alternativa de BCS, 71, pp. 18-21, 2009.

[6] Instituto Nacional de Estadística Geografía e Informática (INEGI), Anuario Estadístico del Estado de Baja California Sur, INEGI: Aguascalientes, Ags., 2007.

[7] Angeles, Manuel, La matriz de contabilidad social de Baja California Sur: algunos resultados en torno a la distribución del ingreso, Alternativa de $B C S$, 41, pp. 13-15, 2004.

[8] Sistema de Consulta, Censos Económicos 2004, Instituto Nacional de Estadística Geografía e Informática (INEGI), on line. www.inegi.gob.mx/ inegi/default.aspx?s=est\&c=10357.

[9] Angeles, M, Sermeño, J. \& Cortés, R., La matriz de contabilidad social de Baja California Sur, UABCS: La Paz, BCS, 2006. 